\title{
Ichthyofauna of Marinheiros Island, Patos Lagoon estuary, southern Brazil
}

\author{
Fernando Quintela ${ }^{I^{*}}$, Fabiano Corrêa ${ }^{2}$, Rafael Martins Pinheiro ${ }^{3}$ \& Daniel Loebmann ${ }^{1}$ \\ ${ }^{1}$ Universidade Federal do Rio Grande, Av. Itália s/n, 96201-900, Rio Grande, RS, Brazil \\ ${ }^{2}$ Universidade Federal do Acre, Rio Branco, AC, Brazil \\ ${ }^{3}$ Universidade do Vale do Itajai, Centro de Ciências Tecnológicas da Terra e do Mar, Itajai, SC, Brazil \\ *Corresponding author: Fernando Quintela,e-mail:fmquintela@yahoo.com.br
}

QUINTELA, F., CORREAA, F., PINHEIRO, R. M., LOEBMANN, D. Ichthyofauna of Marinheiros Island, Patos Lagoon estuary, southern Brazil. Biota Neotropica. 18(1): e20170430. http://dx.doi.org/10.1590/1676-0611-BN-2017-0430

\begin{abstract}
Marinheiros is the largest island of the estuarine archipelago of Patos lagoon and is considered an area of biological relevance in the coastal region of the extreme south of Brazil. Aiming to contribute to the knowledge on the biodiversity of this important area, we conducted an ichthyofaunistic inventory in the limnic environments of the island. Twenty-seven field trips were performed between April 2015 and May 2017. A total of 12 sites representative of habitats of an intermittent shallow lagoon, intermittent pools and a perennial artificial channel were sampled. Sampling of 2,436 specimens revealed the occurrence of 30 species, including the non-native piscivorous Acestrorhynchus pantaneiro. Characiformes was the most diverse order (18 species), followed by Cichliformes (four species) and Cyprinodontiformes (three species). Characiformes was also the most numerically abundant order (77\%) followed by Cichliformes (17.6\%) and Cyprinodontiformes (5.1\%). The species richness recorded in Marinheiros Island is is comparable to the richness observed for lotic systems of southernmost Brazilian coastal plain. The fish assemblage is composed mainly of species of limnic habits whereas few taxa of estuarine-marine-limnic and estuarine-limnic habits were recorded. In view of the presence of allochtonous $A$. pantaneiro and its potential to impact native species, monitoring is recommended to the ichthyofauna of Marinheiros Island and the other estuarine islands, as well as peninsular systems connected to Patos lagoon estuary.
\end{abstract}

Keywords: Acestrorhynchus pantaneiro, ictiocenose, invasive species, Neotropical region

Ictiofauna da Ilha dos Marinheiros, estuário da Lagoa do Patos, sul do Brasil

Resumo: Marinheiros é a maior ilha do arquipélago estuarino da Lagoa dos Patos e é considerada uma área de relevância biológica na região costeira do extremo sul do Brasil. Com o objetivo de contribuir para o conhecimento sobre a biodiversidade desta importante área, realizamos um inventário ictiofaunístico nos ambientes limnicos da ilha. Vinte e sete visitas foram realizadas entre abril de 2015 e maio de 2017. Um total de 12 locais representativos dos habitats de uma lagoa rasa intermitente, poções intermitentes e um canal artificial perene foram amostrados. A amostragem de 2.436 espécimes revelou a ocorrência de 30 espécies, incluindo o piscívoro não-nativo Acestrorhynchus pantaneiro. Characiformes foi a ordem mais diversa (18 espécies), seguido por Cichliformes (quatro espécies) e Cyprinodontiformes (três espécies). Characiformes foi também a ordem mais numericamente abundante (77\%), seguida po Cichliformes $(17,6 \%)$ e Cyprinodontiformes (5,1\%). A riqueza de espécies registrada na Ilha dos Marinheiros é comparável à riqueza observada para sistemas lóticos da planície costeira do extremo sul do Brasil. A assembleia de peixes é composta principalmente por espécies de hábitos límnicos, enquanto que poucos taxa de hábitos estuarino-marinho-límnico e estuarino-límnico foram registrados. Em vista da presença do alóctono A. pantaneiro e seu potencial para impactar espécies nativas, é recomendado o monitoramento da ictiofauna da Ilha dos Marinheiros e de outras ilhas estuarinas, bem como dos sistemas peninsulares conectados ao estuário da Lagoa dos Patos.

Keywords: Acestrorhynchus pantaneiro, ictiocenose, espécie invasora, região Neotropical

\section{Introduction}

Patos lagoon is the world's largest choked lagoon, extending over $240 \mathrm{~km}$ on the southernmost Brazilian coastal plain (Kjerfve 1986). The estuarine zone of Patos lagoon is characterized by the presence an archipelago composed by eight main islands and several islets emerged during the Holocene. Marinheiros is the largest island, covering an area of $62 \mathrm{~km}^{2}$. It is also the first to emerge from the estuarine submerged flats, at about 5,000 years ago, in a process of lagoon sediment deposition (Vieira 1983).

Studies on vertebrate fauna in Marinheiros Island date back only to the last decade and have already highlighted the island as an important area from the biogeographical and conservation perspectives in southern 
Brazilian coast. Sampling efforts on anuran (Quintela et al. 2007, 2009, Bernardo-Silva et al. 2012, Dalmolin et al. 2017), reptilian (Quintela et al. 2011) and avian fauna (Gianuca et al. 2007, 2008, 2012) in the insular environments have identified the occurrence of some unexpected taxa for the region, including the southernmost and isolated population of the threatened red-bellied toad Melanophryniscus dorsalis (Mertens, 1933) (Quintela et al. 2006, Bernardo-Silva et al. 2012). While some groups such as herpetofauna and avifauna are relatively well-known in the island, the ichthyofauna remained practically unexplored. Meanwhile, Marinheiros shelters a peculiar complex of intermittent shallow lagoons and pools, which consist of potential habitats for the fish fauna.

Marinheiros Island is separated from the mainland by approximately $1.7 \mathrm{~km}$ and remained isolated until the year 2004, when the establishment of a bridge linked it to an adjacent island (Leonídeo), which is in turn connected to Rio Grande peninsula. The easy access to Marinheiros resulted in the increase of anthropogenic impacts due to the expansion of settlements and a large increment on tourism and visitation. The insular limnic ecosystems, in particular, also face the threat of pesticides, used in a wide range in the local agricultural production (Quintela et al. 2009, 2011). Thus, pollution and contamination represent potential risks to Marinheiros waterbodies and its associated biota.

Despite the aforementioned importance of Marinheiros for the local biodiversity, the island still lacks an effective plan for the management and conservation of ecosystems, in part due to the gap of knowledge on its biota. Herein, we present the first list of the ichthyofauna occurring in freshwater systems of Marinheiros Island, aiming to contribute to the knowledge on the faunistic diversity in this important area.

\section{Material and Methods}

\section{Study area}

Marinheiros Island $\left(31^{\circ} 58^{\prime}-32^{\circ} 02^{\prime} \mathrm{S} ; 52^{\circ} 05^{\prime}-52^{\circ} 12^{\prime} \mathrm{W}\right)$ is located in the southern portion of Patos lagoon estuary, Rio Grande municipality, Rio Grande do Sul state, southern Brazil. The island is distant about $1.4 \mathrm{~km}$ from the adjacent Leonídeo island, $1.7 \mathrm{~km}$ from peninsular mainland (Rio Grande), and about $16 \mathrm{~km}$ from the estuarine mouth (Figure 1). The climate in Rio Grande municipality is classified as subtropical temperate ( $\mathrm{Cfa}$ of Köppen), with temperatures varying from $9.5^{\circ} \mathrm{C}$ (mean minimum) in midwinter to $27.2^{\circ} \mathrm{C}$ (mean maximum) in midsummer. The average annual rainfall is $1,252 \mathrm{~mm}$ and the rainiest period is from July to September (Vieira 1983).

Hydrographically, Marinheiros Island is characterized mainly by a set of shallow lagoons and pools, strongly influenced by rainfall regime. Some systems can dry completely during periods of high evaporation although heavy rainfall periods can promote the interconnection of systems. Heavy rainfall may also result in the interconnection between internal systems and estuarine waters due to flooding of the peripheral areas of the island. The largest lagoon, locally know as "Lagoa do Rey", can extended over $3.3 \mathrm{~km}$ during rainy period while smaller lagoons range from ca. 150 to $700 \mathrm{~m}$ long. The coverage of marginal areas varies from sandy bottom to dense patches of emergent macrophytes Typha dominguensis Pers., Schoenoplectus californicus (C.A. Mey.) Soják and Scirpus spp. and deeper sections are colonized by the submerged rooted Cabomba caroliniana A. Gray. Bottom varies from sandy in marginal areas to muddy in deeper sections. A set of around 20 pools ranging from 7 to $20 \mathrm{~m}$ in length is located in the eastern portion of the island, know as "Marambaia". The marginal coverage of pools varies from sandy bottom to dense patches of emergent vegetation (mainly T. dominguensis and Scirpus spp.) and some systems are colonized by Nymphoides indica (L.) Kuntzae, Myriophyllum sp. and C. caroliniana. Both pools and lakes do not exceed $2.5 \mathrm{~m}$ in depth and have bottoms varying from sandy to muddy. In addition to these natural hydrographic elements, a pluvial channel extends along the $28 \mathrm{~km}$ of the island perimeter. This artificial system has an average depth of $0.8 \mathrm{~m}$, muddy bottom, and can be densely covered by floating macrophytes (Azolla filiculoides Lam., Eichornia spp., Salvinia spp.) mainly in the warmer periods.
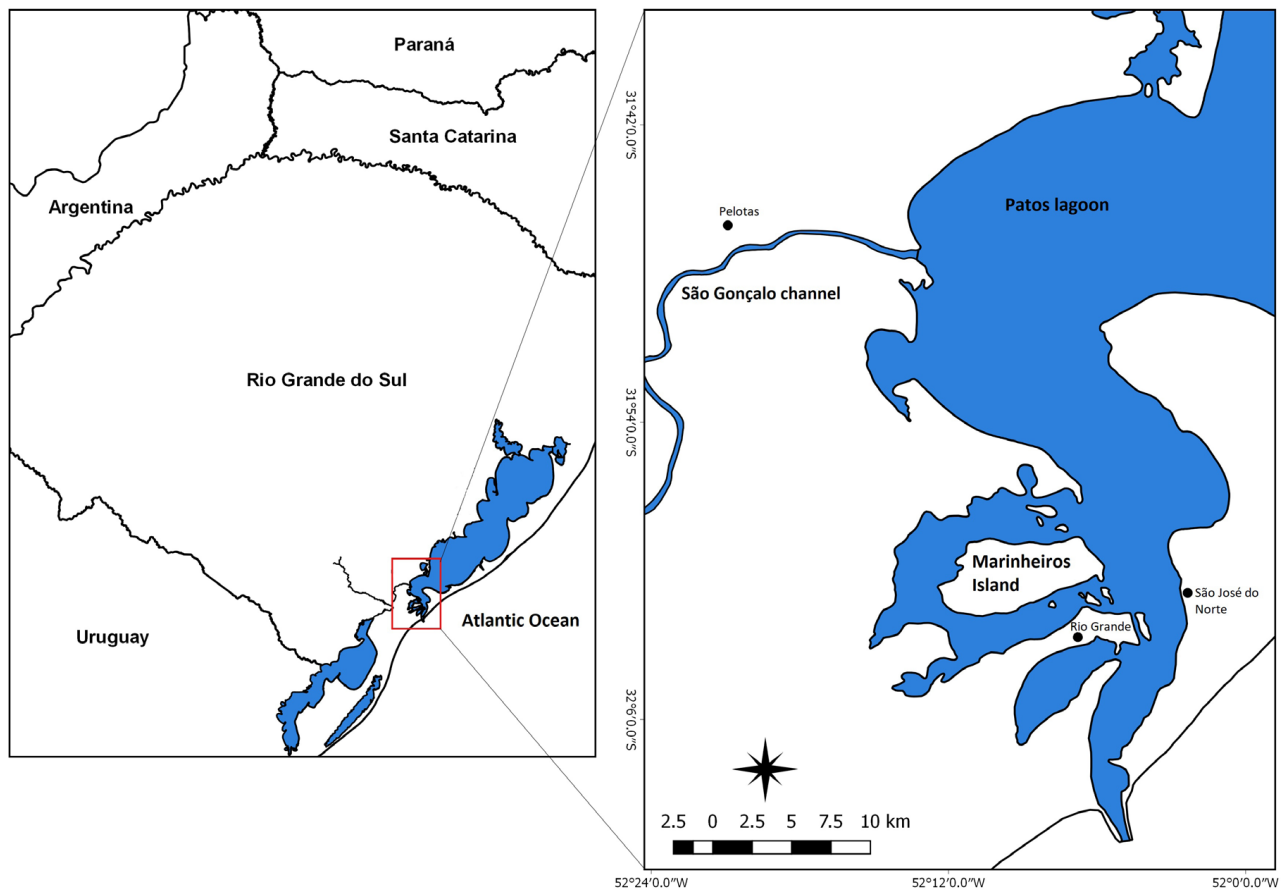

Figure 1. Location of Marinheiros Island, and the sites of collection of the ichthyofauna, Patos Lagoon estuary, southern Brazil. 


\section{Sampling}

Twenty-seven random samplings were conducted between April 2015 and May 2017. A total of 12 sites were sampled, covering environments of the shallow lagoon "Lagoa do Rey", the set of pools "Marambaia" and the pluvial channel (Table 1, Figure 2). Fishes were captured using the following gear: seine net $5 \times 2 \mathrm{~m}$, mesh size $5 \mathrm{~mm}$; gillnet $20 \times 2.5 \mathrm{~m}$, mesh size $7 \mathrm{~mm}$; hand net $0.60 \times 0.40 \mathrm{~m}$, mesh size $2 \mathrm{~mm}$; funnel traps (length $0.74 \mathrm{~m}$, diameter $0.38 \mathrm{~m}$, mesh size $25 \mathrm{~mm}$; length $0.60 \mathrm{~m}$, diameter $0.32 \mathrm{~m}$, mesh size $15 \mathrm{~mm}$ ). Captured individuals were euthanized in clove oil solution, fixed in $10 \%$ formalin and preserved in $70 \%$ ethanol in the Fish Reference Collection of the Instituto de Ciências Biológicas at the Universidade Federal do Rio Grande (CIFURG) (Appendix). Specimens were identified with the help of specialized literature (Reis et al. 2003, Lucinda 2008, Malabarba et al. 2013). Collection was authorized by the Brazilian environmental agency ICMBio through license number 56947-1. Nomenclature of species and higher taxa follows Bertaco et al. (2016).

Table 1. Characteristics and locations of the sites sampled in Marinheiros Island, Patos Lagoon estuary, southern Brazil, and fishing gear applied in each site.

\begin{tabular}{|c|c|c|c|c|}
\hline Site & System & Coordinates & Vegetation & Fish gear \\
\hline 1 & shallow lagoon & $32^{\circ} 01^{\prime} 20^{\prime \prime} \mathrm{S} ; 52^{\circ} 09^{\prime} 28^{\prime \prime} \mathrm{W}$ & submersed/emergent & seine, gill \\
\hline 2 & shallow lagoon & $32^{\circ} 00^{\prime} 58^{\prime \prime} \mathrm{S} ; 52^{\circ} 08^{\prime} 29^{\prime \prime} \mathrm{W}$ & submersed/emergent & seine, gill \\
\hline 3 & shallow lagoon & $32^{\circ} 00^{\prime} 48^{\prime \prime} \mathrm{S} ; 52^{\circ} 08^{\prime} 11^{\prime \prime} \mathrm{W}$ & submersed/emergent & seine, gill \\
\hline 4 & pool & $31^{\circ} 59^{\prime} 54^{\prime \prime} \mathrm{S} ; 52^{\circ} 06^{\prime} 10^{\prime \prime} \mathrm{W}$ & submersed/emergent & seine, gill, funnel \\
\hline 5 & pool & $31^{\circ} 59^{\prime} 54^{\prime \prime} \mathrm{S} ; 52^{\circ} 06^{\prime} 09^{\prime \prime} \mathrm{W}$ & submersed/emergent & seine, funnel \\
\hline 6 & pool & $31^{\circ} 59^{\prime} 54^{\prime \prime} \mathrm{S} ; 52^{\circ} 06^{\prime} 07^{\prime \prime} \mathrm{W}$ & submersed/emergent & funnel, handnet \\
\hline 7 & pool & $31^{\circ} 59^{\prime} 53^{\prime \prime} \mathrm{S} ; 52^{\circ} 06^{\prime} 06^{\prime \prime} \mathrm{W}$ & submersed/emergent & seine, funnel \\
\hline 8 & pool & $31^{\circ} 59^{\prime} 52^{\prime \prime} \mathrm{S} ; 52^{\circ} 06^{\prime} 06^{\prime \prime} \mathrm{W}$ & submersed/emergent & seine, funnel \\
\hline 9 & pool & $31^{\circ} 59^{\prime} 50^{\prime \prime} \mathrm{S} ; 52^{\circ} 06^{\prime} 04^{\prime \prime} \mathrm{W}$ & submersed/emergent & seine, funnel \\
\hline 10 & pool & $31^{\circ} 59^{\prime} 49^{\prime \prime} \mathrm{S} ; 52^{\circ} 06^{\prime} 03^{\prime \prime} \mathrm{W}$ & submersed/emergent & seine, funnel \\
\hline 11 & channel & $31^{\circ} 59^{\prime} 15^{\prime \prime} \mathrm{S} ; 52^{\circ} 06^{\prime} 58^{\prime \prime} \mathrm{W}$ & emergent & gill, funnel, handnet \\
\hline 12 & channel & $31^{\circ} 59^{\prime} 09^{\prime \prime} \mathrm{S} ; 52^{\circ} 07^{\prime} 06^{\prime \prime} \mathrm{W}$ & floating/emergent & funnel, handnet \\
\hline
\end{tabular}

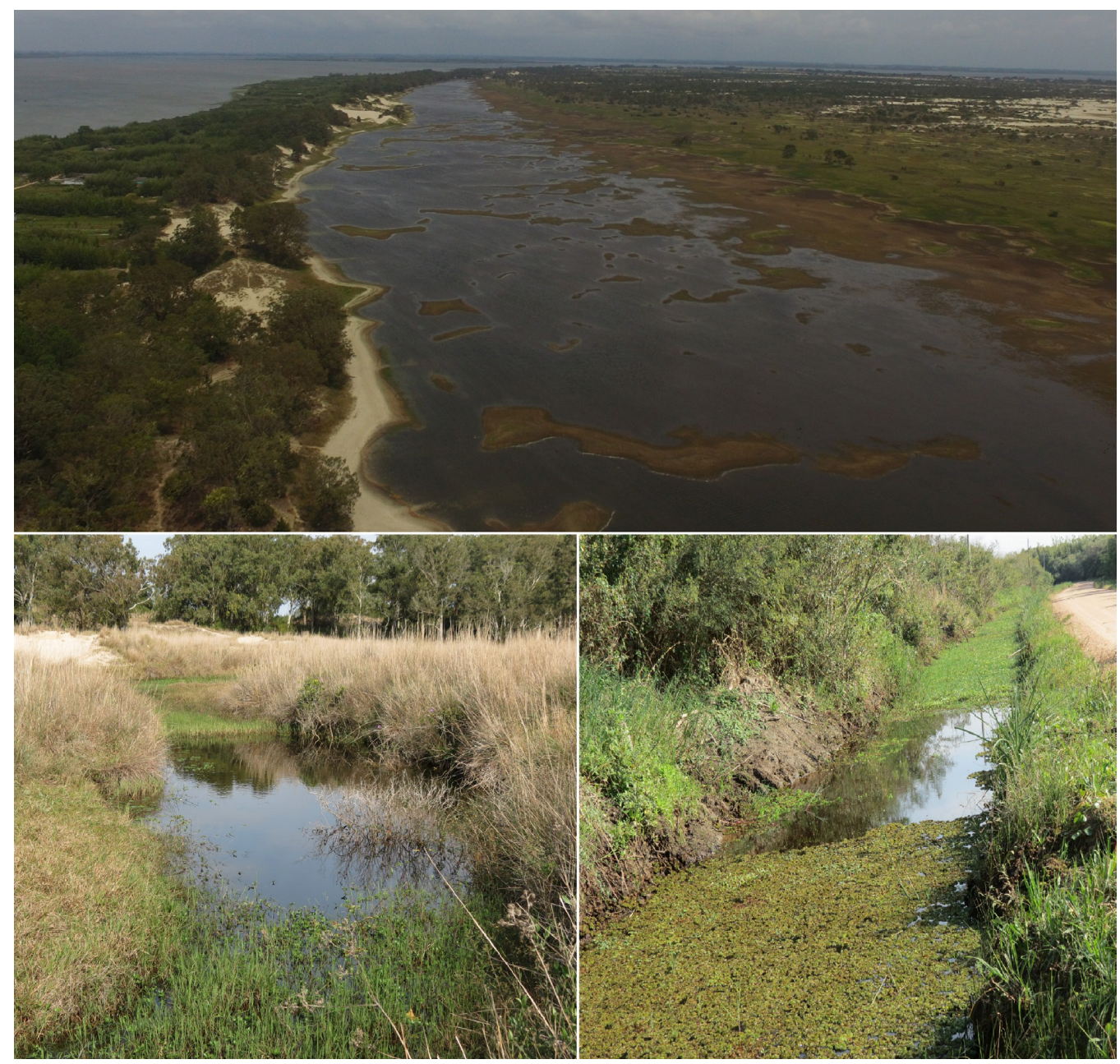

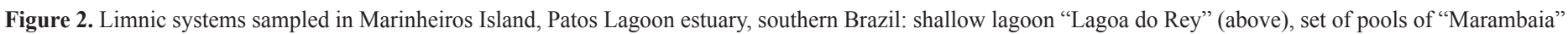
(below, left); pluvial channel (below, right). 


\section{Results}

A total of 2,436 specimens belonging to 30 species, 21 genera, 11 families and six orders was collected (Table 2). Characiformes was the order with the highest species richness (18 species), followed by Cichliformes (four species) and Cyprinodontiformes (three species). Characiformes was the most numerically abundant order (77\%), followed by Cichliformes (17.6\%) and Cyprinodontiformes (5.1\%). Characidae was the most rich family (14 species) and also the most abundant family (74.8\%). Cichlidae was the second most diverse (four species) and abundant family (17.6\%). All species except Acestrorhynchus pantaneiro Menezes, 1992 (Figure 3) are native to Patos lagoon basin (Saccol-Pereira et al. 2006, Assumpção et al. 2016).

Table 2. Number of collected specimens and relative abundance (in parentheses) of fish species recorded in three types of limnic systems in Marinheiros Island, Patos Lagoon estuary, southern Brazil.

\begin{tabular}{|c|c|c|c|c|}
\hline Taxon & Pools & Shallow lagoon & Channel & Subtotal \\
\hline Acestrorhynchus pantaneiro Menezes, 1992 & $2(0.13)$ & & & $2(0.08)$ \\
\hline Astyanax eigenmanniorum (Cope, 1894) & $649(43.44)$ & $76(9.48)$ & & $725(29.76)$ \\
\hline Astyanax lacustris (Lütken, 1875) & $4(0.26)$ & & & $4(0.16)$ \\
\hline Astyanax henseli Melo \& Buckup, 2006 & $1(0.06)$ & & & $1(0.04)$ \\
\hline Cheirodon interruptus (Jenyns, 1842) & $99(6.62)$ & $195(24.34)$ & & $294(12.06)$ \\
\hline Hyphessobrycon anisitsi (Eigenmann, 1907) & & $21(2.62)$ & & $21(0.86)$ \\
\hline Hyphessobrycon boulengeri (Eigenmann, 1907) & $2(0.13)$ & & $28(19.85)$ & $30(1.23)$ \\
\hline Hyphessobrycon luetkenii (Boulenger, 1887) & $79(5.28)$ & $470(58.67)$ & $12(8.51)$ & $561(23.02)$ \\
\hline Hyphessobrycon igneus Miquelarena, Menni, López \& Casciotta, 1980 & $87(5.82)$ & $7(0.87)$ & $12(8.51)$ & $106(4.35)$ \\
\hline \multicolumn{5}{|l|}{ Erythrinidae } \\
\hline Hoplias malabaricus (Bloch, 1794) & $6(0.40)$ & $3(0.37)$ & $1(0.71)$ & $10(0.41)$ \\
\hline \multicolumn{5}{|l|}{ Curimatidae } \\
\hline Cyphocharax saladensis (Meinken, 1933) & & $3(0.37)$ & & $3(0.12)$ \\
\hline Cyphocharax voga (Hensel, 1870) & $38(2.54)$ & & $1(0.71)$ & $39(1.60)$ \\
\hline \multicolumn{5}{|l|}{ Cichliformes } \\
\hline \multicolumn{5}{|l|}{ Cichlidae } \\
\hline Australoheros acaroides (Hensel, 1870) & $6(0.40)$ & & & $6(0.24)$ \\
\hline Cichlasoma portalegrense (Hensel, 1870) & $194(12.98)$ & $3(0.37)$ & $1(0.71)$ & $198(8.12)$ \\
\hline Crenicichla lepidota Heckel, 1840 & $107(7.16)$ & $1(0.12)$ & $2(1.41)$ & $110(4.51)$ \\
\hline Geophagus brasiliensis (Quoy \& Gaimard, 1824) & $90(6.02)$ & $2(0.24)$ & $24(17.02)$ & $116(4.76)$ \\
\hline Pimelodella australis Eigenmann, 1917 & $1(0.06)$ & & & $1(0.04)$ \\
\hline Rhamdia aff. quelen (Quoy \& Gaimard, 1824) & $2(0.13)$ & & & $2(0.08)$ \\
\hline \multicolumn{5}{|l|}{ Cyprinodontiformes } \\
\hline \multicolumn{5}{|l|}{ Anablepidae } \\
\hline Jenynsia multidentata (Jenyns, 1842) & $44(2.94)$ & $20(2.49)$ & & $64(2.62)$ \\
\hline \multicolumn{5}{|l|}{ Poeciliidae } \\
\hline Phalloceros caudimaculatus (Hensel, 1868) & $4(0.26)$ & & $55(39.00)$ & $59(2.42)$ \\
\hline Poecilia vivipara Bloch \& Schneider, 1801 & & & $1(0.71)$ & $1(0.04)$ \\
\hline \multicolumn{5}{|l|}{ Synbranchiformes } \\
\hline \multicolumn{5}{|l|}{ Synbranchidae } \\
\hline Synbranchus marmoratus Bloch, 1795 & & & $2(1.4)$ & $2(0.08)$ \\
\hline Total & 1494 & 801 & 141 & 2436 \\
\hline
\end{tabular}




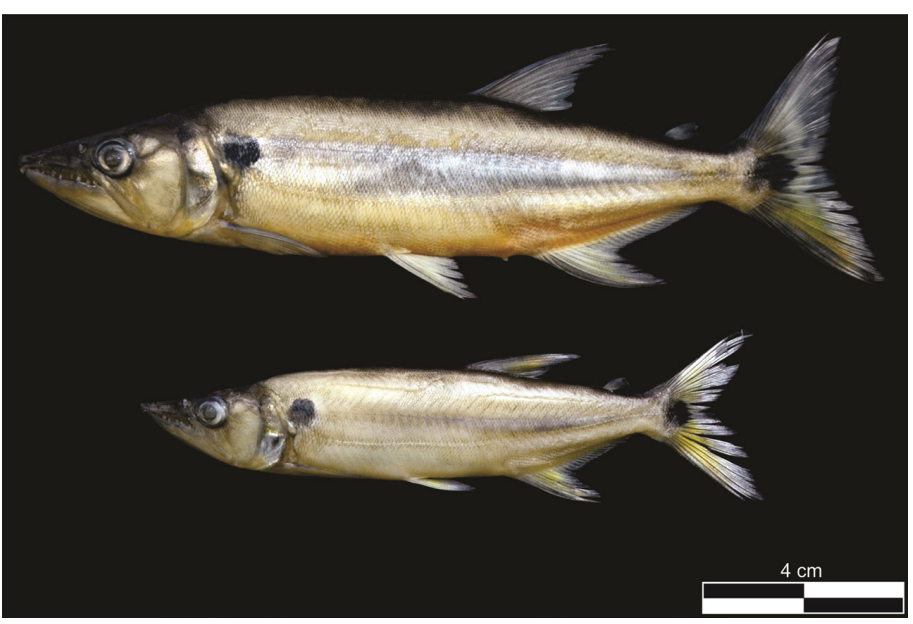

Figure 3. Specimens of Acestrorhynchus pantaneiro (above CIFURG 200, below CIFURG 201) collected in Marinheiros Island, Patos Lagoon estuary, southern Brazil.

None of the recorded species is considered as threatened in Rio Grande do Sul (FZB 2014) and Brazilian (MMA 2014) lists.

The set of pools was the systems with the highest richness recorded (25 species), followed by the pluvial channel (13 species) and the shallow lagoon "Lagoa do Rey" (11 species). The characids Astyanax eigenmanniorum (Cope, 1894) and Hyphessobrycon luetkenii (Boulenger, 1887) were the most abundant species in the pools set and the shallow lagoon, respectively. The poeciliid Phalloceros caudimaculatus (Hensel, 1868) was the most abundant species in the pluvial channel. The number of collected specimens and the relative abundance of recorded species in each sampled system are given in Table 2 .

\section{Discussion}

The limnic enviroments of Marinheiros Island house an ichthyofaunistic diversity within the range observed for lotic systems in southernmost Brazilian coastal plain, which is between 22 (Fortaleza lagoon; Schifino et al., 2004) and 67 species (Peixe lagoon; Loebmann \& Vieira 2005). It is clear the taxonomic and numerical dominance of order Characiformes, with family Characidae encompassing around $46 \%$ of the species richness and $75 \%$ of all specimens collected. The high diversity of Characiformes corroborates the general pattern found in Neotropical region (Reis et al. 2003), as well as the regional patterns observed in all of the limnic systems of the southernmost Brazilian coastal plain studied so far, where Characidae stands out as the richest family (Assumpção et al. 2016). The shallow depths of island systems are favorable to the occurrence of characids, which are referred as inhabitants mainly of shallow waters (Lowe-McConnell 1987). However, the most speciose order in Rio Grande do Sul state (Bertaco et al. 2016), Siluriformes, was poorly represented in the insular systems, with only two recorded species (Pimelodella australis Eigenmann, 1917 and Rhamdia aff. quelen Quoy \& Gaimard, 1824). It is possible that the great predominance of shallow zones in the systems acts limiting the occurrence of species of this order, usually benthic and inhabitants of deeper zones (Malabarba et al. 2013). Cichlidae, the second most diverse family in Marinheiros, is also among the most rich fish groups in Neotropical region (Kullander 2003) and it is well represented in limnic environments of Rio Grande do Sul coastal plain (Assumpção et al. 2016). Moreover, the insular systems of Marinheiros present physiognomic characteristics such low depths, abundance of aquatic macrophytes and sandy bottoms, which are considered suitable for the cichlids occurrence (Malabarba et al. 2013).

Except by Jenynsia multidentata (Jenyns, 1824), Ctenogobius shufeldti (Jordan \& Eigenmann, 1887) (both estuarine-limnic) and Dormitator maculatus (Bloch, 1792) (marine-estuarine-limnic), all the remain recorded species exhibit limnic habits (see Assumpção et al. 2016). Marinheiros Island, as well as the other estuarine islands in Patos lagoon estuary, is strongly subject to flooding during the periods of high precipitation and consequent high discharge of Patos-Mirim basin. Under this condition, estuarine waters overrun a considerable stretch of the borders of the island, including the peripheral freshwater systems. Thus, it was expected a higher representativeness of coastal marine and estuarine-related species which also inhabit freshwater coastal environments of the region, such as Atherinella brasiliensis (Quoy \& Gaimard, 1825), Mugil spp., Micropogonias furnieri (Desmarest, 1823), Odontesthes argentinensis (Valenciennes, 1835), O. bonariensis (Valenciennes, 1835), Platanichthys platana (Regan,1917) and others (see Tagliani 1994, Loebmann \& Vieira 2005, Garcia et al. 2006, Artioli et al. 2009, Bastos et al. 2013), were absent in our sampling. It should be noted that the insular systems were also sampled subsequently to the heavy rainfall period associated to last El Niño (2015-2016), when Patos Lagoon estuarine archipelago experienced severe flooding events. This fact can be related to the strong influence of the precipitation in the insular systems, which may decrease the salinity in short time after estuarine floods, making the environments little attractive for the coastal and estuarine-related species.

The capture of two individuals of Acestrorhynchus pantaneiro, an invasive species in Patos lagoon basin (Saccol-Pereira et al. 2006), is remarkable. Acestrorhynchus pantaneiro is a piscivorous medium-sized species (maximum total length $35 \mathrm{~cm}$ ) (Zaniboni et al. 2004), native to Mamoré, Paraguay, Paraná and Uruguay rivers basins (Menezes 2003). In the southernmost Brazilian state of Rio Grande do Sul, A. pantaneiro is considered autochthonous solely for Uruguay basin (Menezes 2003, Saccol-Pereira et al. 2006). About a decade, it also has been found in Patos-Mirim and Tramandaí basins (Saccol-Pereira et al. 2006, Leal et al. 2009, Artioli et al. 2013, Rocha and Hartz 2013, Einhardt et al. 2014, Corrêa et al. 2015, Neuhaus et al. 2016), where it is considered an invasive species in rapid expansion (Neuhaus et al. 2016). Nevertheless, our record is the first in the estuarine zone of Patos lagoon. Considering that Patos lagoon estuary was systematically sampled in the last decade (Garcia et al. 2003, Garcia et al. 2004, Burns et al. 2006), it is possible that the species settled this area only recently.

Piscivorous invasive fish species show a tendency for establishment, promoting disturbances in trophic cascades and populations of native species (Pusey et al. 2006). Neuhaus et al. (2016) verified a high food niche overlap between invasive $A$. pantaneiro and native Oligosarcus robustus Menezes, 1969 in Jacuí and Sinos rivers, northern Patos Lagoon basin, were both species predated predominantly on small characids. Thus, if $A$. pantaneiro became an established invasive species in Marinheiros Island, populations of $O$. robustus and other native species may be directly affected by resource competition and predation. In view of this, we recommend the monitoring of $A$. pantaneiro and the ichthyofauna of limnic systems of Marinheiros in general, as well as other estuarine islands and systems of the peninsular systems of the coastal plain connected to the estuary of Patos lagoon. This procedure could detect new areas of occurrence of $A$. pantaneiro and collect data for the analysis on the relationships between this invasive species and the native ichthyofauna. 


\section{Supplementary material}

The following online material is available for this article:

Appendix 1: List of vouchers housed in the Fish Reference Collection of FURG (CIFURG).

\section{Acknowledgements}

We are grateful to CAPES (Coordenação de Aperfeiçoamento de Pessoal de Nível Superior) for the postdoctoral fellowship granted to FMQ; Victor Teixeira for help in fieldwork; Juliano Ferrer and one anonymous reviewer for the comments and suggestions to the first version of this manuscript.

\section{Author Contributions}

Fernando Marques Quintela: contribution to conception and design of the study; contribution to data sampling and analysis; contribution to manuscript preparation.

Fabiano Corrêa: contribution to data analysis; contribution to manuscript preparation.

Rafael Martins Pinheiro: contribution to data sampling; contribution to manuscript preparation.

Daniel Loebmann: contribution to manuscript preparation and critical revision.

\section{Conflicts of interest}

The authors declare that they have no conflict of interest related to the publication of this manuscript.

\section{References}

ARTIOLI, L.G.S., VIEIRA, J.P., GARCIA, A.M. \& BEMVENUTI, M.A. 2009 Distribuição, dominância e estrutura de tamanhos da assembleia de peixes da lagoa Mangueira, sul do Brasil. Iheringia Sér. Zool. 99(4): 409-418.

ARTIOLI, L.G.S., NETO, P.C., MAIA R. \& FIALHO, C.B. 2013. First Record of the non-native species Acestrorhynchus pantaneiro Menezes, 1992 (Characiformes, Acestrorhynchidae) in the Tramandaí River system, Rio Grande do Sul, Brazil. Pan-Am. J. Aquat. Sci.8(1): 51-54.

ASSUMPÇÃO, C.M., QUINTELA, F.M., CORREA, F. \& LOEBMANN, D. 2016. The ichthyofauna of limnic systems in Quaternary deposits of extreme southern Brazil. ZooKeys 638: 83-104.

BASTOS, R.F., CONDINI, M.V \& GARCIA, A.M. 2013. Fish species list of coastal streams in southern Brazil, with notes on austral distribution limits of marine and freshwater endangered species. Pan-Am. J. Aquat. Sci. 8(4): 347-351.

BERNARDO-SILVA, J., MARTINS-FERREIRA, C., MANEYRO, R. \& FREITAS T.R.O. 2012. Identification of priority areas for conservation of two endangered parapatric species of red-bellied toads using ecological niche models and hotspot analysis. Nat. \& Conserv. 10(2): 207-213.

BERTACO, V.A., FERRER J., CARVALHO, F.R. \& MALABARBA, L.M. 2016 Inventory of the freshwater fishes from a densely collected area in South America - a case study of the current knowledge of Neotropical fish diversity. Zootaxa 4138(3): 401-440.

BURNS, M.D.M., GARCIA, A.M., VIEIRA, J.P., BEMVENUTI, M.A., MARQUES D.M.L.M. \&CONDINI, M.V. 2006. Evidence of habitat fragmentation affecting fish movement between the Patos and Mirim coastal lagoons in southern Brazil. Neotrop. Ichthyol. 4(1): 69-72.

CORRÊA, F., OLIVEIRA E.F., TUCHTENHAGEN, T., POUEY, J. \& PIEDRAS, S.2015. Ichthyofauna of the hydrographic basin of the Chasqueiro Stream (Mirim Lagoon system, southern Brazil): generating subsidies for conservation and management. Biota Neotrop. 15(4): 1-13. DOI: 10.1590/1676-0611-BN2015-0006

DALMOLIN, D.A., ROSA, F.O., FREIRE, M.D., FONTE, L.F.M., MACHADO, I.F., PAULA, C.N., LOEBMANN, D. \& PERICO, E. 2017. First record of the
Lesser Snouted Treefrog Scinax nasicus (Cope, 1862) in Brazilian coast and new species records for the state of Rio Grande do Sul. Braz. J. Biol. 76: 1-3.

EINHARDT, M.D.S., CORREAA, F., CAVALHEIRO, A.C.M., PIEDRAS, S.R.N., \& POUEY, J. 2014. New area of occurrence to Acestrorhynchus pantaneiro (Menezes, 1992) (Characiformes, Acestrorhynchidae) in the Chasqueiro stream basin, Patos-Mirim system, Rio Grande do Sul, Brazil. Bol. Soc. Zool. Uruguay 23(1): 36-42.

FZB - FUNDAÇÃO ZOOBOTÂNICA DO RIO GRANDE DO SUL. 2014. Lista das espécies da fauna gaúcha ameaçada de extinção. http://www.fzb.rs.gov.br/uploa $\mathrm{d} / 201409091158080909014$ especiesameacadas.pdf (last access in 22/11/2017).

GARCIA, A.M., VIEIRA, J.P., BEMVENUTI, M.A., MOTTA-MARQUES, D.M.L., BURNS, M., MORESCO, A. \& CONDINI, V. 2006. Checklist comparison and dominance patterns of the fauna at Taim Wetland, South Brazil. Neotrop. Icththyol. 4(2): 261-268.

GARCIA, A.M., VIEIRA, J.P. \& WINEMILLER, K.O.2003.Effects of 1997-1998 El Niño on the dynamics of the shallow-water fish assemblage of the Patos Lagoon estuary (Brazil). Estuar. Coast. Shelf Sci.57 (3): 489-500.

GARCIA, A.M., VIEIRA, J.P., WINEMILLER, K.O. \& GRIMM, A.M.2004. Comparison of 1982-1983 and 1997-1998 El Niño effects on the shallow-water fish assemblage of the Patos Lagoon estuary (Brazil). Estuaries 27(6): 905-914.

GIANUCA, D. 2007. Ocorrência sazonal e reprodução do socó-caranguejeiro Nyctanassa violacea no estuário da Lagoa dos Patos, novo limite sul da sua distribuição geográfica. Rev. Bras. Ornitol. 15(3): 464-467.

GIANUCA, D., QUINTELA, F.M., BARROS, J.A., GOMES jr., A., GIANUCA, N.M. 2008. Ocorrência regular da garça-azul Egretta caerulea (Ciconiiformes, Ardeidae) no estuário da Lagoa dos Patos, Rio Grande do Sul, Brasil. Pan-Am. J. Aquat. Sci. 3(3): 328-334

GIANUCA, D., GIANUCA, A. \&VOOREN, C.M. 2012. Abundance, breeding and food of the Little Blue Heron (Egretta caerulea) in the Patos Lagoon estuary, a recently colonized area in southern Brazil. Iheringia. Sér. Zool. 102(1): 19-25.

KJERFVE, B. 1986. Comparative oceanographic of coastal lagoons. In Estuarine variability (D.A Wolfe, ed.). Academic Press, New York, p.63-81.

KULLANDER, S.O. 2003. Family Cichlidae. In Checklist of the Freshwater Fishes of South and Central America (RE Reis, SO Kullander and CJ Ferraris Jr eds). Edipucrs, Porto Alegre, p.605-654.

LEAL, M.E., BREMM, C.Q. \& SCHULZ, U.H. 2009. Lista da ictiocenose da bacia do Rio dos Sinos, Sul do Brasil. Bol. Inst. Pesca 35(2): 307-317.

LOEBMANN, D. \& VIEIRA, J.P. 2005. Distribuição espacial e abundância das assembléias de peixes no Parque Nacional da Lagoa do Peixe, Rio Grande do Sul, Brasil. Rev. Bras. Zool. 22(3): 667-675.

LOWE-MCCONNELL. R.H. 1987. Ecological studies in tropical fish communities Cambridge University Press, Cambridge.

LUCINDA, P.H.F. 2008. Systematics and biogeography of the genus Phalloceros Eigenmann, 1907 (Cyprinodontiformes: Poeciliidae: Poeciliinae), with the description of twenty-one new species. Neotrop. Ichthyol. 6(2): 113-158.

MALABARBA L.R., CARVALHO-NETO P., BERTACO, V.A., CARVALHO, T.P., SANTOS, J.F. \& ARTIOLI, L.G.S. 2013: Guia de identificação dos peixes da Bacia do Rio Tramandaí. Via Sapiens, Porto Alegre.

MENEZES, N.A. 2003. Família Acestrorhynchidae. In Checklist of the Freshwater Fishes of South and Central America (R.E. Reis, S.O. Kullander \& C.J. Ferraris Jr eds.). Edipucrs, Porto Alegre, p.432-433.

MMA - MINISTÉRIO DO MEIO AMBIENTE. 2014. Lista Nacional das Espécies da Fauna Brasileira Ameaçadas de Extinção. http://www.mma.gov.br/biodiversidade/ especies-ameacadas-de-extincao/fauna-ameaçada (last access in 22/11/2017).

PUSEY, B., BURROWS, D., ARTHINGTON, A. \& KENNARD, M. 2006 Translocation and spread of piscivorous fishes in the Burdekin River, northeastern Australia. Biol. Invasions 8(4): 965-977.

QUINTELA, F. M., MEDVEDOVISKY, I.G., IBARRA, C., NEVES, L.F.M. \& FIGUEIREDO, M.R.C. 2011. Reptiles recorded in Marinheiros Island, Patos Lagoon estuary, southern Brazil. Herpetol. Notes 4: 57-62.

QUINTELA, F.M., MEDVEDOVISKY, I.G., NEVES, L.F.M., LOEBMANN, D. \& FIGUEIREDO, M.R.C. 2007. Amphibia, Anura, Bufonidae, Melanophryniscus 
dorsalis: distribution extension in the state of Rio Grande do Sul, Brazil. Check List 3(2): 100-103.

QUINTELA, F. M. NEVES, L.F.M., MEDVEDOVISKY, I.G., SANTOS, M.B., OLIVEIRA, M.C.L.M. \&FIGUEIREDO, M.R.C. 2009. Relação dos anfíbios da Ilha dos Marinheiros, estuário da Lagoa dos Patos, Rio Grande do Sul, Brasil. Rev. Bras. Bioc. 7(2): 231-233.

REIS, R.E., KULLANDER, S.O. \& FERRARIS jr, C.J. 2003. Check list of the freshwater fishes of South and Central America. Edipucrs, Porto Alegre.

ROCHA, E.A. \& HARTZ, S.M. 2013. Estabilidade e persistência de uma comunidade de peixes em lagoa costeira neotropical. Rev. Bras. Bioc. 11(2): 149-156.

SACCOL-PEREIRA, A., MILANI, P.C.C. \& FIALHO, C.B. 2006. Primeiro registro de Acestrorhynchus pantaneiro Menezes, 1992 (Characiformes, Acestrorhynchidae) no sistema da laguna dos Patos, Rio Grande do Sul, Brasil. Biota Neotrop. 6(3): 1-4. DOI: $10.1590 /$ S1676-06032006000300017
SCHIFINO, L.C., FIALHO, C.B. \& VERANI, J.R. 2004. Fish community composition, seasonality and abundance in Fortaleza Lake, Cidreira. Braz. Arch. Biol. Technol. 47(5): 755-763.

TAGLIANI, P.R.A. 1994. Ecologia da assembléia de peixes de três riachos da planície costeira do Rio Grande do Sul. Atlântica 16: 55-68.

VIEIRA, E.F. 1983: Rio Grande: Geografia Física, Humana e Econômica. Sagra, Porto Alegre.

ZANIBONI, E., MEURER, S., SHIBATTA, O.A. \& NUÑER, A.P.O. 2004. Catálogo ilustrado de peixes do alto rio Uruguai. UFSC, Florianópolis.

Received: $21 / 08 / 2017$

Revised: 15/12/2017

Accepted: 07/01/2018

Published online: 15/01/2018 